\title{
MOVEMENT OF ROMANIAN CITIZENS IN EUROPE
}

\author{
M. Tudorascu
}

\author{
Miruna Tudorascu \\ "1 Decembrie 1918" University from Alba Iulia, Alba Iulia, Romania \\ *Correspondence: Miruna Tudorascu, Lecturer PhD, "1 Decembrie 1918” University from \\ Alba Iulia, 11-13 "Nicolae Iorga” St., Alba Iulia, Romania \\ E-mail: miruna.tudorascu@yahoo.com
}

\begin{abstract}
This right is stipulated in the Treaty of Lisbon, which amends paragraph 2 of art. 17 of TEC, as recognizing the right of Union citizens to move and reside freely within the Member States territory. This right can be exercised but only under the conditions and limits defined by treaties and by the measures adopted to implement them.
\end{abstract}

Keywords: treaty, limits, right, free movement, measure.

\section{Introduction}

Treaty establishing the European Community (TEC) settled European citizenship, setting in the art. 17 that "any citizen of the Union has the nationality of a Member State"; EU citizens enjoy the rights provided by TEC, one of which is entitled to travel and live where they want on Member States territory (art. 18 of the Treaty).

Correlative to the right of the free movement, the Treaty is governing the circumstances in which this freedom may be restricted. According to art. 39 of the Treaty, restrictions on freedom of movement may be justified only on grounds of public order, public safety and public health.

This right is stipulated in the Treaty of Lisbon, which amends paragraph 2 of art. 17 of TEC, as recognizing the right of Union citizens to move and reside freely within the Member States territory. This right can be exercised but only under the conditions and limits defined by treaties and by the measures adopted to implement them.

The limits of the right of free movement of EU citizens have been laid down by art. 27 of the Directive no. 2004/38/EC of 29.04.2004 on freedom of movement and residence within Member States territory for Union citizens and their family members (the Directive). Under these rules, Member States may restrict the free of movement of Union citizens and their family members, regardless of nationality, only for reasons of public order, public security or public health. The taken measures must comply with the proportionality and to be based solely on the personal conduct of the person concerned. ${ }^{1}$ This conduct must represent a genuine, present and sufficiently dangerous to justify the measure of restriction of free movement. ${ }^{2}$

In Romania's accession to the European Union was necessary to transpose the Directive no. 2004/38/EC into national law. Legislature intended for that purpose to issue two

\footnotetext{
${ }^{1}$ Octavian Manolache, Drept comunitar, All Beck Publishing House, Ed. IV th, Bucharest, 2003, p. 247-248; Felician Cotea, Dreptul comunitar al afacerilor, Mediamira Publishing House, Cluj Napoca, 2005, p. 53

2 According to art. 27 of the Directive. 2004/38/CE/29.04.2004, Member States may restrict freedom of movement and residence of Union citizens and their family members, regardless of nationality, on grounds of public policy, public security or public health. These reasons can not be relied on for economic purposes (para. 1). Measures taken on grounds of public policy or public security must respect the principle of proportionality and be based solely on the person's conduct. Previous criminal convictions can not in itself justify taking such measures. Conduct of the person concerned must represent a genuine, present and sufficiently serious threat to the fundamental interests of society. Will not be accepted motives which are not directly related to the case or on considerations of general prevention (para. 2).
} 
laws, namely: Government Emergency Ordinance (GEO) no. 102/2005, regarding the free movement of citizens of EU Member States on the Romania territory, and the Law no. 248/2005 on the free movement of Romanian citizens abroad.

Analyzing the restrictions of free movement of persons, it is found that when they were taken into account as citizens of EU member states have fully complied with the Directive, GEO No. 102/2005, in fact in art. 25, para. 1, that: "Romanian competent authorities are able to restrict the right of free circulation in Romania for the European Union citizens or their family members only on grounds of public policy, national security or public health".

Instead, when he covered the free movement of Romanian citizens abroad, the national legislature ignored the restrictions from Directive, and by art. no. 38 from The Law no 248/20053, established that: "restriction of free movement of Romanian citizens abroad can be for a period not exceeding three years, only under conditions andregarding the following persons:

a)

b)

the person who was returned from a state based on a readmission agreement signed between Romania and that country;

b) the person whose presence in a State, through the work they perform or would perform, would seriously prejudice the interests of Romania and, where appropriate, bilateral relations between Romania and that State."

After 1 st of January 2007, courts were obliged to examine the compatibility of national law on the free movement of persons with Community law and jurisprudence.

The national judge became, thereafter, the Community judge, beeing obliged to apply directly the Community law if he finds it incompatible with national law, under principles of direct effect of Community law and its supremacy ${ }^{5}$.

Also, the national court were not able to apply national law contrary to Community law. Thus, any national court must, in a case of falling within its jurisdiction, to apply Community law in its entirety and to protect the rights which it are confered to citizens, what it means to ignore any provision of national law which may conflict with Community law, either before or after entry into force of the Community Rules. ${ }^{6}$

Based on these principles laid down by Community law, court must be examined to what extent are compatible with Community law, provisions of domestic law on free movement of Romanian citizens abroad, provided that, in the limiting cases of this law, domestic law does not transpose the Directive.

In this regard, we note that the Community provides an exhaustive rule only in three situations in which the state could restrict freedom of movement of persons: effect on public policy, public security or public health.

The reason of public policy may be invoked in cases where it finds that there is a genuine and serious undermining of the fundamental interests of society. Although Community law does not prescribe a uniform scale of values regarding the assessment of behaviors that could be considered to be contrary to public policy, a behavior could not be considered as sufficiently serious to justify restrictions on freedom of movement across a member of a national of another Member State, if not the first state, reported the same behavior of their citizens, repressive measures or other genuine and effective measures to combat this behavior.

Court of Justice of European Communities has stated that this exception should be seen through the individual behavior of a person, so it can not be arranged collective expulsions or

\footnotetext{
${ }^{3}$ Law no. 248 of 20 July 2005 on the free movement of Romanian citizens abroad was published in Official Gazette no. 682 of July 29, 2005.

${ }^{4}$ The case 26/62, The Court Decizion from 05.02.1963, Van Gend en Loos c. Administraţie der Belastingen; The Case C 8/81, The Court Decizion from 19.01.1982, Becker v. Finanzamt Munster - Innenstadt.

${ }^{5}$ The Case C 6/64, The Court Decizion from 15.07.1964, Costa c. E.N.E.L.

6 The Case 106/77, The Court Decizion from 09.03.1978, Amministrazione delle Finanze dello Stato c. Simmenthal.
} 
for preventive purposes. In this context, the fact that a person has a criminal record is not automatically a reason to refuse entry into another Member State ${ }^{7}$, while membership in an organization considered being dangerous in the receiving country, entitles the authorities to refuse entry into their territory or to issue a residence card. ${ }^{8}$

As regards to the second ground of limitation or restriction of free movement, the Community legislature considered the notions of public order and public security as beeing distinct, however the Court of Justice of European Communities treats them as synonymous. However, the literature suggested that the public policy should understand everything about the foundation of society, individual freedom and security, and the public security and state security foundation. ${ }^{9}$

In the exception based on public health, the only diseases justifying measures of restriction of free movement are diseases with epidemic potential, as it defines the relevant OMS documents, and other infectious diseases or contagious parasitic diseases if they are the subject of protective provisions applying to nationals of the host Member State.

The Diseases occurring after a period of three months from the date of arrival shall not constitute grounds for expulsion from the territory.

If the Directive expressly provides limited situations that may be restricted the freedom of movement of EU citizens, that includes and Romanian citizens, instead, internal standard, namely Law no. 248/2005, in its original form, provides the possibility of the restriction of the free movement if the Romanian citizen was returned from a state based on a readmission agreement.

It is seen that internal law does not make any assessment of the person concerned citizen, that if you represent a danger to public order, public safety or health of the state from he has been returned.

The Internal Rule provides a broader category of situations where it can have the right to restrict the free movement of Romanian citizens in relation to the category of exceptional circumstances provided for by Community.

It follows that the internal rule is partially incompatible with Community standards in relation to other exceptions to the free movement of persons than those concerning policy, public security or public health.

With the Directive 2004/38/EC is clear, unconditional and sufficiently precise and the Romanian State has not transposed into national law before accession, under the direct effect of Community law, national courts will apply the provisions of the Directive and not those contained in Law no. 248/2005.

Domestic courts seized on the restriction of free movement for "illegally staing" on the basis of readmission agreements, have consistently held that the settlement involves assessing the compatibility of the domestic law with the Community Law.

It was thus found that art. 18 (1) TEC is directly applicable in national domestic law, so that EU citizens, including Romanian citizens have the right to leave the territory of a Member State, including Member State of origin, to enter the territory of another Member State. ${ }^{10}$

The right to move freely within the Member States as it is stipulated and guaranteed by Article 18 (1) TEC, includes the right to leave the home. This fundamental right would be

\footnotetext{
${ }^{7}$ In a recent decision of 7th of June 2007 in Case C 50/60, Commission v. Netherlands, stated that Community law precludes national provisions based on the presumption that nationals of other Member States who have been convicted to a specific punishment for specific offenses must be expelled. This is because such expulsion is a measure that would severely affect people using the rights and freedoms conferred by the Treaty have been effectively integrated in the host. Consequently, the greater the degree of integration of EU citizens and their families in the host, the greater would be their degree of protection against expulsion.

${ }^{8}$ F. Cotea, op. cit., p.76-77.

${ }^{9}$ B. Goldman, A. Lyon-Caen, L. Voegel, Droit commercial europeen, Dalloz, Paris, 1994, p. 238.

${ }^{10}$ In this respect the High Court of Cassation and Justice ruled, for example, civil decisions no.1109/2010, no. Or No 7337/2009. 2119/2008.
} 
deprived of its substance unless the Member State may, without a good reason, to prohibit their nationals to leave its territory in order to enter the territory of another Member State.

The national judge found that the national provision - Article 38 of Law no. 248/2005 contrary to Community law, so it requires the application of Community law for the right to leave the state.

A Member State may not limit the right to leave the home state automatically, just because a person has been expelled from another member state "illegally staing" without examining the personal conduct and without assessing the proportionality of the measure sought and purpose.

The mere failure to comply with conditions set by State law, concerning the right of residence in its territory of a Romanian citizen, can not be framed within notions of order, safety or public health, referred to the relevant provisions of Community rules for to be accepted by the applicant brought proceedings. ${ }^{11}$

It is true that the Court, the Court of Justice of European Communities, does not prohibit to Member States to adopt legislation that would restrict the right of a national of a Member State to move in another Member State, but such limitations should be confined to situations expressly provided for by Community Directive 2004/38/EC and that, in any case, the measures required can not violate the principle of proportionality in relation to the purpose. $^{12}$

Although the practice of the courts in our country has been constant in the analysis of standard compatibility with EU law and to apply directly the provisions of the Directive, the Court Dambovita made the Crew in 2007 and agreed reference for a preliminary interpretation of art. 18 TEC and Art. 27 of Directive 2004/38/EC.

In July 2008, the Court of Justice of European Communities ruled ${ }^{13}$ that the two Community provisions do not preclude national legislation, which allows restricting the right of a national of a Member State to move on the territory of another Member State, especially because it was previously returned from this state because the situation there was "illegally staing".

The Court stressed that it is necessary, first, that national conduct to represent a genuine, present and sufficiently serious threat to the fundamental interests of society, and, on the other hand, restrictive measure considered to be appropriate to ensure attainment of the objective pursued and not go beyond what is necessary to achieve it. As a result, the Court concluded, it is the national court to determine whether these requirements are met.

\section{Conclusions}

Therefore, the Court of Justice of European Communities (CJEC) has confirmed that even for the the restriction of free movement for "illegally staing", has to be ascertain whether this limitation is necessary to comply with EU rules and values quoted in proportion to damage to these values but necessarily to be analyzed also the national's conduct.

\footnotetext{
${ }^{11}$ For example, the civil no.6208/2009 decision, High Court of Cassation held that the expulsion of respondent is not itself sufficient to prohibit the right of free movement of Romanian citizens on its territory. Also, the civil decision no. 7297/2009, High Court of Cassation ruled that although the defendant has been detained several times by the Italian police, it is not evidence of the commission of antisocial acts that would affect Romania's relations with Italy, for the purposes envisaged by the Directive 2004/38 referring to limits the right of entry and residence on grounds of public policy, public security or public health.

${ }^{12}$ Thus, the civil decision no. 63/A/2009 from Alba Iulia Court of Appeal, unpublished, it was established that it is unnecessary to restrict freedom of movement of the person who worked as a windshield washer in France, without being attached to said relevant departments, whereas no evidence that it committed no such acts of endangering public order, namely that its behavior is a genuine, present and sufficiently serious threat to public order.

7 The case C-33/07, The Cours Decision from 10 iulie 2008, The Ministery of Administration and Internal General Direction of Passports, Bucharest/Gheorghe Jipa.
} 
The practice of national courts and the Court of Justice of European Communities upheld the Romanian legislature to coroborate provisions of Law no. 248/2005 with EU rules.

Thus, by Law no. 206/2010 was repealed the art. 38, paragr. a, of Law no. 248/2005, which imposed restrictions of the freedom of movement for Romanian citizens returned from a state, based on a readmission agreement, in fact for "illegally staing" on the territory of another state.

\section{Bibliography}

Felician Cotea, Dreptul comunitar al afacerilor, Mediamira Publishing House, Cluj Napoca, 2005;

Octavian Manolache, Drept comunitar, All Beck Publishing House, Bucharest, 2003; 1994.

B. Goldman, A. Lyon-Caen, L. Voegel, Droit commercial europeen, Dalloz, Paris, 